\title{
Leaf heat tolerance of 147 tropical forest species varies with elevation and leaf functional traits, but not with phylogeny
}

\author{
Martijn Slot ${ }^{1}$, Daniela Cala ${ }^{1}$, Jorge Aranda ${ }^{1}$, Aurelio Virgo ${ }^{1}$, Sean Michaletz ${ }^{2}$, and Klaus \\ Winter $^{1}$ \\ ${ }^{1}$ Smithsonian Tropical Research Institute \\ ${ }^{2}$ Affiliation not available
}

November 27, 2020

\begin{abstract}
Exceeding thermal thresholds causes irreversible damage and ultimately loss of leaves. The lowland tropics are among the warmest forested biomes, but little is known about heat tolerance of tropical forest species. We surveyed leaf heat tolerance of sun-exposed leaves from 147 tropical lowland and pre-montane forest species by determining the temperatures at which potential photosystem II efficiency based on chlorophyll a fluorescence started to decrease $\left(\mathrm{T}_{\text {Crit }}\right)$ and had decreased by $50 \%\left(\mathrm{~T}_{50}\right)$. $\mathrm{T}_{\text {Crit }}$ averaged $46.7^{\circ} \mathrm{C}\left(5^{\text {th }}-95^{\text {th }}\right.$ percentile: $\left.43.5-49.7^{\circ} \mathrm{C}\right)$ and $\mathrm{T}_{50}$ averaged $49.9^{\circ} \mathrm{C}\left(47.8-52.5^{\circ} \mathrm{C}\right)$. Heat tolerance partially adjusted to site temperature; $\mathrm{T}_{\mathrm{Crit}}$ and $\mathrm{T}_{50}$ decreased with elevation by $0.40^{\circ} \mathrm{C}$ and $0.26^{\circ} \mathrm{C}$ per $100 \mathrm{~m}$, respectively, while mean annual temperature decreased by $0.63^{\circ} \mathrm{C}$ per $100 \mathrm{~m}$. The phylogenetic signal in heat tolerance was weak, suggesting that heat tolerance is more strongly controlled by environment than by evolutionary legacies. $\mathrm{T}_{\mathrm{Crit}}$ increased with the estimated thermal time constant of the leaves, indicating that species with thermally buffered leaves maintain higher heat tolerance. Among lowland species, $T_{50}$ increased with leaf mass per area, so species with structurally more costly leaves reduce the risk of leaf loss during hot spells. These results provide insight in interspecific variation in heat tolerance at local and regional scales.
\end{abstract}

Leaf heat tolerance of 147 tropical forest species varies with elevation and leaf functional traits, but not with phylogeny

Running head: heat tolerance of tropical forest plants

Martijn Slot ${ }^{1}$, Daniela Cala ${ }^{1}$, Jorge Aranda ${ }^{1}$, Aurelio Virgo ${ }^{1}$, Sean T. Michaletz ${ }^{2}$, Klaus Winter ${ }^{1}$

${ }^{1}$ Smithsonian Tropical Research Institute, Apartado Postal 0843-03092, Panama City, Republic of Panama

${ }^{2}$ Department of Botany and Biodiversity Research Centre, University of British Columbia, Vancouver, BC, Canada

Corresponding author: Martijn Slot. Smithsonian Tropical Research Institute, Apartado Postal 0843-03092, Panama City, Republic of Panama. Email: slotm@si.edu

\section{Funding}

This research was supported by the Smithsonian Tropical Research Institute (STRI). MS was recipient of the Earl S. Tupper- STRI postdoctoral fellowship. DC was supported by a Hollister-Smith Endowment-funded STRI internship.

\section{Abstract}

Exceeding thermal thresholds causes irreversible damage and ultimately loss of leaves. The lowland tropics are among the warmest forested biomes, but little is known about heat tolerance of tropical forest species. 
We surveyed leaf heat tolerance of sun-exposed leaves from 147 tropical lowland and pre-montane forest species by determining the temperatures at which potential photosystem II efficiency based on chlorophyll afluorescence started to decrease $\left(\mathrm{T}_{\text {Crit }}\right)$ and had decreased by $50 \%\left(\mathrm{~T}_{50}\right)$. $\mathrm{T}_{\text {Crit }}$ averaged $46.7^{\circ} \mathrm{C}\left(5^{\text {th }}-\right.$ $95^{\text {th }}$ percentile: $\left.43.5-49.7^{\circ} \mathrm{C}\right)$ and $\mathrm{T}_{50}$ averaged $49.9^{\circ} \mathrm{C}\left(47.8-52.5^{\circ} \mathrm{C}\right)$. Heat tolerance partially adjusted to site temperature; $\mathrm{T}_{\text {Crit }}$ and $\mathrm{T}_{50}$ decreased with elevation by $0.40^{\circ} \mathrm{C}$ and $0.26^{\circ} \mathrm{C}$ per $100 \mathrm{~m}$, respectively, while mean annual temperature decreased by $0.63^{\circ} \mathrm{C}$ per $100 \mathrm{~m}$. The phylogenetic signal in heat tolerance was weak, suggesting that heat tolerance is more strongly controlled by environment than by evolutionary legacies. $\mathrm{T}_{\text {Crit }}$ increased with the estimated thermal time constant of the leaves, indicating that species with thermally buffered leaves maintain higher heat tolerance. Among lowland species, $\mathrm{T}_{50}$ increased with leaf mass per area, so species with structurally more costly leaves reduce the risk of leaf loss during hot spells. These results provide insight in interspecific variation in heat tolerance at local and regional scales.

\section{Keywords}

climate thresholds, chlorophyll $a$ fluorescence, functional traits, global warming, heat tolerance, phylogenetics, thermoregulation, tropical forest

\section{Acknowledgements}

Ernesto Campos and other STRI herbarium staff helped with species identification. We thank F. Andrew Jones for discussions about phylogenetic approaches, and S. Joseph Wright and Oswaldo Calderon for sharing information on species deciduousness.

\section{Introduction}

The effect of global environmental change on life on earth often exhibits threshold dynamics in which performance steeply and irreversibly drops off above or below a critical threshold (Scheffer 2009). One example is the heat tolerance of ectotherms: beyond a critical temperature threshold $\left(\mathrm{T}_{\mathrm{Crit}}\right)$ performance rapidly declines, eventually resulting in irreversible damage typically only a few degrees above $\mathrm{T}_{\text {Crit }}$, as shown in e.g. arthropods (García-Robledo et al . 2016; Franken et al . 2018), amphibians and reptiles (e.g., Duarte et al . 2012), as well as in primary producers such as phytoplankton (Padfield et al . 2016) and terrestrial plants (e.g., Sachs 1864; Sapper 1935; Knight \& Ackerly 2003; Krause et al . 2010). To better anticipate the consequences of rising temperatures for ectotherms it will be important to understand variation in thermal thresholds among co-occurring species within a community and among different communities. Because of the dependence of virtually all organisms on primary producers, understanding thermal thresholds of photosynthesizing organisms is particularly important.

More than 150 years ago, Sachs (1864) reported that plants in his university's botanical garden could withstand exposure to air temperatures up to $50^{\circ} \mathrm{C}$ without leaf damage, but that $51^{\circ} \mathrm{C}$ or higher temperatures killed the leaves. Later studies reported more variation in heat tolerance, with both lower and higher values being observed in the early $20^{\text {th }}$ century (Sapper 1935), but it remained challenging to identify general patterns underlying this variation. In recent years leaf heat tolerance has received renewed interest as ongoing global warming and more frequent and intense heatwaves may push ecosystems past their critical thermal thresholds (Feeley et al. 2020a; Lancaster \& Humphreys 2020; Perez \& Feeley 2020a,b; Geange et al. 2021). Recent studies have shown that heat tolerance increases from the poles towards the tropics (O'Sullivan et al . 2017) and from high elevation to low elevation (Feeley et al . 2020a), in parallel with increasing temperatures under which plants develop. While consistent, the increase in thermal thresholds along these gradients is moderate: $0.38^{\circ} \mathrm{C}$ per ${ }^{\circ} \mathrm{C}$ increase in mean maximum temperature of the warmest month from poles to the tropics, and $<0.1^{\circ} \mathrm{C}^{\circ} \mathrm{C}^{-1}$ mean annual temperature from high to low elevation. Furthermore, at each latitude and elevation heat tolerance varies considerably among species, and the mechanisms underlying this variation have not been explored in detail.

Variation in heat tolerance among co-occurring species may represent functional or ecological differences in micro-climate adaptation among species. For example, Sapper (1935) already showed that sun species have higher heat tolerance than shade species, and Slot et al . (2018) showed that even within species, heat 
tolerance tends to be moderately higher in sun leaves than in shade leaves. Within site variation may also reflect different evolutionary histories of plants. Dick et al . (2013) reported that many common Neotropical tree species have emerged long enough ago to have previously experienced climatological conditions not unlike those predicted for the end of the current century. As such, Dick et al . (2013) proposed, these survivors of past extreme climates may be more likely to tolerate high temperatures than species in contemporary Neotropical forests that have emerged more recently under relatively cooler conditions. Neotropical forests have existed for at least $\sim 58$ million years (Wing et al . 2009) and are characterized not only by high species diversity, but also by great diversity at higher taxonomic levels. For example, on 50 hectares of forest in central Panama $>300$ species of woody plants with $>1 \mathrm{~cm}$ stem diameter have been identified, belonging to $>60$ families, including ancient families such as Fabaceae and Lecythidaceae and families of more recent origins such as Chrysobalanaceae and Apocynaceae. Within site variation of temperature sensitivity may thus also be related to the evolutionary history of species.

Tropical forest trees routinely experience high temperatures when exposed to direct irradiance, especially during moments of low wind speed, with leaf temperatures exceeding air temperature by as much as $10-18^{\circ} \mathrm{C}$ (Doughty \& Goulden 2008; Rey-Sanchez et al . 2016; Fauset et al . 2018). Leaf traits can influence both the magnitude and rate of leaf heating (Jones 2013). For example, greater leaf width and leaf size are generally associated with a larger leaf boundary layer and greater decoupling of leaf and air temperatures (Jones 2013). Indeed, Fauset et al . (2018) parameterized a leaf energy balance model for tropical montane species and found that leaf width was the most important leaf morphological driver of species differences in the leaf-to-air temperature differential. Multiple leaf traits can also be combined into composite traits that characterize the dynamics of leaf temperatures. For example, the thermal time constant $(\tau \cdot s)$ quantifies the thermal stability of a leaf, i.e. how rapidly leaf temperature responds to temporal variation in microclimate (Michaletz et al . $2015,2016)$. The low $\tau$ of relatively small and thin leaves indicates that they heat up and cool down quickly, so that leaf temperatures essentially track changes in microclimate variables, including very high temperatures when in full sun. By contrast, leaves with a comparatively large thermal mass and a high $\tau$ are buffered against fluctuations in microclimate, so that leaf temperatures lag behind changes in microclimate variables (Michaletz et al . 2015, 2016). Leaf temperature can also be affected by transpirational cooling, especially in hot and dry environments (Lin et al. 2017), and thus stomatal conductance is another potentially relevant leaf trait. However, because of the prevalence of mid-day stomatal depression (Zotz et al. 1995; Goulden et al. 2004; Kosugi et al. 2008), the highest leaf temperatures are experienced when stomata are closed, and maximum stomatal conductance is therefore unlikely to distinguish maximum temperatures across species. Furthermore, a sensitivity analysis revealed that variation in stomatal conductance had virtually no effect on the thermal time constant $\tau$ (Michaletz et al. 2016)

One would expect a strong selective advantage of high heat tolerance in species that have traits that cause them to experience high maximum temperatures. Indeed, heat tolerance scaled with maximum recorded leaf temperatures in a botanical garden in Florida (Perez \& Feeley 2020a). High heat tolerance would likewise seem advantageous for species with traits that result in high temperatures being maintained for long periods of time. The rapid response to warming of low $\tau$ species should predispose them to experiencing higher maximum temperatures, whereas the slow cooling high $\tau$ species maintain high temperatures longer once they are reached. The photosynthetic capacity of species with low $\tau$ peaks at higher ambient temperatures than for species with high $\tau$, suggesting that species with low $\tau$ are better acclimated to higher temperatures than high $\tau$ species (Michaletz et al . 2016). Whether low $\tau$ species also have higher heat tolerances under field conditions has not yet been tested.

Leaves that are structurally relatively costly to produce need to last long enough for the plant to offset the investment, and therefore tend to be better protected against biotic (Coley 1987) and abiotic stressors (Nardini et al . 2012). Correspondingly, high heat tolerance of such leaves would be expected. This has indeed been observed for plants experiencing distinct temperature seasonality (e.g., Knight \& Ackerly 2003; Sastry \& Barua 2017), but whether this pattern is maintained in more thermally stable ecosystems such as tropical forests remains to be tested. 
We measured leaf heat tolerance for 147 tropical species from lowland and pre-montane forest sites in Panama and tested the following hypotheses:

1) Heat tolerance will be greater in species growing in lowland than in pre-montane sites, consistent with previously observed relationships between heat tolerance and growth temperature. Based on previous observations we expect this difference to be smaller than the difference in growth temperature. Over a $20^{\circ} \mathrm{C}$ growing season temperature range from the arctic to the tropics, mean heat tolerance increased by only $9^{\circ} \mathrm{C}$ (O'Sullivan et al . 2017), and over a $17^{\circ} \mathrm{C}$ mean annual temperature range across a tropical elevation gradient, Feeley et al . (2020a) reported an increase in heat tolerance of less than $2^{\circ} \mathrm{C}$. These observations suggest that upper temperature thresholds are relatively high in cool conditions and increase only moderately with growth temperature.

2) Heat tolerance will be phylogenetically structured and lineages that can be considered survivors of past hot epochs will have higher heat tolerance than species or lineages that emerged later and are naïve to such conditions.

3) Heat tolerance will increase with traits that enable leaves to reach high temperature extremes, such that species that quickly heat up will have higher heat tolerance than species that are more buffered against high temperatures. This would be consistent with Perez \& Feeley (2020a) and with the higher temperature optimum for photosynthesis of low $\tau$ species (Michaletz et al . 2016). Alternatively, heat tolerance may be greater in thermally buffered species because they cool down more slowly and thus maintain stable temperatures for longer. Heat tolerance may differ with duration of exposure; when individual leaves are warmed gradually over a wide temperature range (commonly by $1^{\circ} \mathrm{C}$ per minute) heat tolerance is often relatively low, suggesting a negative effect of the cumulative heat exposure (Krause et al. 2010). If the negative impact of sustained high temperatures is greater than that of higher, but shorter peak temperatures, heat tolerance might correlate positively with $\tau$ across species.

4) Species that produce structurally expensive leaves will have higher heat tolerance than species with 'cheap' leaves that can be readily replaced. High investment in leaves that are relatively thick and dense (high LMA), or with high leaf dry matter content (LDMC), is associated with higher leaf longevity (Wright et al . 2004), and thus with greater likelihood of the leaves experiencing temperature extremes during their lifetime.

\section{Materials and Methods}

\section{Site information}

Samples were collected from plants growing in six regions in the Republic of Panama (Table 1; Fig. S1). We extracted mean, minimum, and maximum monthly temperatures for each study site from WorldClim 2.0 (Fick \& Hijmans, 2017), which provides spatially interpolated monthly climate variables with an accuracy of $\sim 1 \mathrm{~km}^{2}$. For the lowland sites additional climate data were available from the Physical Monitoring Program of the Smithsonian Tropical Research Institute, and from the Panama Canal Authority (Table S1). The WorldClim data correlated very well with the monitored data $\left(\mathrm{R}^{2}=0.9\right.$. Table S1) and for consistency we used WorldClim data for all sites in the analyses.

Species selection and sample collection

We collected samples from 147 tropical forest species from 54 families from lowlands up to pre-montane forests in the Republic of Panama between February 2019 and January 2020. We also included two species of Agave cultivated at the Smithsonian Tropical Research Institute's Santa Cruz plant growth facilities in Gamboa, and an invasive grass common in forest edges. In Panama there is no evidence for seasonal changes in heat tolerance for the species for which this has been tested (Krause et al . 2010) as temperature seasonality is minimal. Fig. S2 shows measured heat tolerance parameters through the collection period, showing no indication of seasonal patterns. Species included gymnosperms (5) but mostly consisted of angiosperms (145) - primarily trees (129), but also palms (2), lianas and vines (5), large woody shrubs (5), large forbs (3), and a grass (1) (Table S2). ForAcacia mangium, we measured phyllodes instead of leaves. The vast 
majority of the species are native to Panama (134), but several common non-native species were included (16), most of them ornamentals.

Sun-exposed outer canopy leaves were collected using (pole) pruners, where possible from multiple individuals $(n=1-4$, mean 1.5). For each species vouchers were collected and deposited at the herbarium of the University of Panama (PMA). At Parque Nacional San Lorenzo, canopy leaves were accessed with the aid of a construction crane maintained by the Smithsonian Tropical Research Institute. CAM plants were collected in the afternoon of sunny days to make sure that leaf acid content was low, as vacuolar release of these acids from fully acidified tissues during sample preparation can exacerbate leaf damage and significantly lower estimates of heat tolerance (Krause et al . 2016). All other species were collected in the morning to reduce the risk of sampling heat-stressed or photoinhibited leaves - this included the facultative CAM species Clusia minor and $C$. pratensis that were sampled during the wet season when expressing $\mathrm{C}_{3}$. Branches were enclosed in large opaque plastic bags with moist tissue paper until processed in the laboratory in Panama City on the same day.

\section{Chlorophyll a fluorescence protocol}

Following Krause et al . (2010) we measured $\mathrm{F}_{\mathrm{v}} / \mathrm{F}_{\mathrm{m}}$ on leaf disks 24 hours after they were incubated for 15 minutes in a temperature-controlled water bath, using 8-12 incubation temperatures between 44 and $54^{\circ} \mathrm{C}$ (where necessary $58^{\circ} \mathrm{C}$ ), with a minimum of five leaf disks at each temperature. When multiple individuals were sampled for a species, they were pooled, and at each temperature a random set of leaf discs was used. Leaf surfaces were first cleaned with distilled water. Leaf disks (typically $2 \mathrm{~cm}$ diameter, or smaller when leaves were narrow) were wrapped into strips of miracloth (Calbiochem, La Jolla, CA) - to avoid hypoxic conditions - and then put into individual small zip-lock bags with small glass rods at the bottom. The bags were placed in preheated water baths (Lauda RM6/RMS circulating water bath or Lauda Alpha immersion thermostat; Analytical Instruments, LLC, Golden Valley, MN, USA). After 15 minutes the miracloth was removed and the disks transferred to moist tissue paper in petri dishes. Samples were allowed to recover for 24 hours at low $\left(<10 \mu \mathrm{mol} \mathrm{m} \mathrm{s}^{-1}\right)$ photosynthetically active radiation to ensure that the reductions in fluorescence yield were irreversible and not transient in nature. We then measured the initial Chl afluorescence emission $\left(\mathrm{F}_{0}\right)$, maximum fluorescence $\left(\mathrm{F}_{\mathrm{m}}\right)$, and recorded the ratio of variable $\left(\mathrm{F}_{\mathrm{m}}{ }^{-}\right.$ $\left.\mathrm{F}_{0}\right)$ to maximum fluorescence $\left(\mathrm{F}_{\mathrm{v}} / \mathrm{F}_{\mathrm{m}}\right)$ after dark adaptation for 15 min. Measurements were made with a PAM-2000 and a mini-PAM fluorometer (Walz GmbH, Effeltrich, Germany).

\section{Heat tolerance parameters}

We calculated three temperature-response parameters of $\mathrm{F}_{\mathrm{v}} / \mathrm{F}_{\mathrm{m}}: \mathrm{T}_{\text {Crit }}$, the critical temperature beyond which $\mathrm{F}_{\mathrm{v}} / \mathrm{F}_{\mathrm{m}}$ declines and leaves are irreversibly heat damaged; $\mathrm{T}_{50}$, the temperature at which PSII functionality is reduced by $50 \%$; and $\mathrm{b}$, the steepness of the decrease in $\mathrm{F}_{\mathrm{v}} / \mathrm{F}_{\mathrm{m}}$ around $\mathrm{T}_{50} . \mathrm{T}_{50}$ and $\mathrm{b}$ were determined by fitting the data with Eqn 1 as:

$F_{v} / F_{m}=\frac{F_{v} / F_{m}, \text { Control }}{1+e^{b \times\left(T_{\text {Leaf }}-T_{50}\right)}}$ Eqn 1

where $\mathrm{F}_{\mathrm{v}} / \mathrm{F}_{\mathrm{m} \text {,Control }}$ is the average $\mathrm{F}_{\mathrm{v}} / \mathrm{F}_{\mathrm{m}}$ of control leaves that were not heat treated, and $\mathrm{T}_{\text {Leaf }}$ is the incubation temperature $\left({ }^{\circ} \mathrm{C}\right)$ of the leaf disks. Curves were fitted with the 'nls_multstart' function from the 'nls.multstart' package (Padfield \& Metheson 2018) in R version 3.6.1 (R Core Team 2019). The curves thus generated enabled us to generate species-level parameter estimates with their standard errors. $\mathrm{T}_{\text {Crit }}$ was calculated as the temperature at which a line describing the slope of the $\mathrm{F}_{\mathrm{v}} / \mathrm{F}_{\mathrm{m}}$ decline at $\mathrm{T}_{50}$ intersected with a horizontal line indicating $\mathrm{F}_{\mathrm{v}} / \mathrm{F}_{\mathrm{m}, \mathrm{Control}}$.

\section{Functional traits}

Leaf traits were measured on at least five leaves per species. Fresh mass was measured on fully hydrated leaves. Leaf length and width were measured with digital calipers or rulers, and leaf lamina thickness was recorded on at least three positions from the apical, median and basal section for each leaf using a digital micrometer. We measured leaf area with a LI-3100C area meter (LI-COR, Lincoln, NE). Dry mass was determined after 
drying the leaves at $70^{\circ} \mathrm{C}$. From these measurements we calculated leaf mass per area (LMA, $\mathrm{kg} \mathrm{m}^{-2}$ ), leaf dry matter content (LDMC, $\mathrm{g} \mathrm{g}^{-1}$ ), and leaf density (leaf dry mass per unit leaf volume). To address hypothesis 3 we estimated leaf thermal time constant $\tau$ (s) from first principles following Michaletz et al . (2015), using species-level mean values of LMA, LDMC, leaf area, and leaf width; mean annual temperature derived from WorldClim2; and wind speed set to $2 \mathrm{~m} \mathrm{~s}^{-1}$, as:

$\tau=\varphi L M A\left[\frac{c_{p, w}}{L D M C \cdot h}+\frac{c_{p, d}-c_{p, w}}{h}\right] \operatorname{Eqn} 2$

where $\varphi$ (dimensionless) is the ratio of projected-to-total leaf area, $c_{p, d}\left(\mathrm{~J} \mathrm{~kg}^{-1} \mathrm{~K}^{-1}\right)$ is the specific heat capacity of dry leaf matter, and $c_{p, w}\left(\mathrm{~J} \mathrm{~kg}^{-1} \mathrm{~K}^{-1}\right)$ is the specific heat capacity of water. The heat transfer coefficient $h\left(\mathrm{~W} \mathrm{~m}^{-2} \mathrm{~K}^{-1}\right)$ was calculated as $h=\rho_{a} c_{p, a} g_{h}$, where $\rho_{a}\left(\mathrm{~kg} \mathrm{~m}^{-3}\right)$ is air density, $c_{p, a}\left(\mathrm{~J} \mathrm{~kg}^{-1} \mathrm{~K}^{-1}\right)$ is the specific heat capacity of air at a constant pressure, and $g_{h}$ is the heat conductance. The effects of radiation and transpiration were not included as these data were not available for all species. This permits us, however, to quantify how variation in the measured morphological traits alone causes variation in thermal time constants. Functional trait data were obtained for 132 species as insufficient healthy leaves were available for all species. For species with compound leaves we used traits (LMA, size, $\tau$, etc) collected on leaflets for further analyses. Where necessary, traits were transformed to improve normality of the data.

Phylogenetic analyses

We constructed a phylogenetic tree of all identified species $(\mathrm{n}=144)$ with the V.PhyloMaker package (Jin \& Qian 2019) in R, which generates phylogenies for vascular plants using two mega-trees as a backbone (Zanne et al . 2014; Smith \& Brown 2018). Trait variation was mapped onto the phylogeny using the Phytools package (Revell 2012), which was also used to test for phylogenetic signals in heat tolerance and other leaf traits. Phylogenetic signals were evaluated with Blomberg's K parameter (Blomberg et al . 2003) and with Pagel's $\lambda$ (Pagel, 1999). In the absence of significant phylogenetic signal in heat tolerance parameters (see below), regression of these parameters against other leaf traits were performed with ordinary least squares, which is the appropriate method regardless of phylogenetic patterns in the traits themselves (Revell 2010).

\section{Results}

$\mathrm{T}_{50}$ of the tropical forest species averaged $50.0 \pm 1.5^{\circ} \mathrm{C}$ (mean $\pm \mathrm{SD}$ ) and ranged from $45.8^{\circ} \mathrm{C}$ in Hedyosmum bonplandianum, a montane forest tree, to $53.7^{\circ} \mathrm{C}$ in Rhizophora mangle, the pan-tropical red mangrove (Table S2), with $90 \%$ of observations falling between 47.8 and $52.5^{\circ} \mathrm{C}$. Even higher values were found in nonforest CAM plants, with $\mathrm{T}_{50}$ of $55^{\circ} \mathrm{C}$ in Agave americana. Within ecosystems there was also a considerable range in $\mathrm{T}_{50}$ values: among the 117 lowland species, values ranged from $47.7^{\circ} \mathrm{C}$ in Luehea speciosa to $53.5^{\circ} \mathrm{C}$ in Cecropia longipes. $\mathrm{T}_{\text {Crit }}$ likewise varied considerably, from $42.0^{\circ} \mathrm{C}$ in $H$. bonplandianum to $50.9^{\circ} \mathrm{C}$ in the palm Dypsis lutescens, with an average of $46.7 \pm 2.0^{\circ} \mathrm{C}$ and $90 \%$ of observations falling between 43.5 a

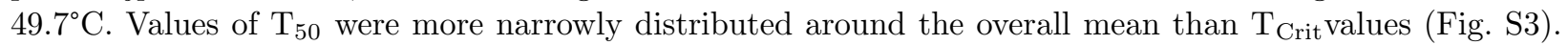
$\mathrm{T}_{50}$ and $\mathrm{T}_{\text {Crit }}$ were highly correlated $\left(\mathrm{F}_{1,150}=231.2, p<0.001, \mathrm{r}^{2}=0.61\right) . \mathrm{T}_{50}$ was on average $3.2^{\circ} \mathrm{C}$ higher than $\mathrm{T}_{\mathrm{Crit}} . \mathrm{F}_{\mathrm{v}} / \mathrm{F}_{\mathrm{m}}$ declined more steeply around $\mathrm{T}_{50}$ in species in which the decline started at a higher temperature, i.e., the distance between $\mathrm{T}_{\text {Crit }}$ and $\mathrm{T}_{50}$ decreased as $\mathrm{T}_{\mathrm{Crit}}$ increased. This was indicated by a decrease in the $\mathrm{b}$ parameter - $\mathrm{b}$ becoming more negative - with increasing $\mathrm{T}_{\text {Crit }}\left(\mathrm{F}_{1,150}=62.2, p<0.001\right.$, $\left.\mathrm{r}^{2}=0.29\right)$.

\section{Effects of elevation and site temperature on heat tolerance and leaf traits}

$\mathrm{T}_{50}$ and $\mathrm{T}_{\text {Crit }}$ both decreased significantly with elevation $\left(\mathrm{F}_{1,150}=35.1\right.$ and 46.1 , for $\mathrm{T}_{50}$ and $\mathrm{T}_{\text {Crit }}$, respectively, $p<0.001$ ) (Fig. 1). Including CAM and $\mathrm{C}_{4}$ plants in the analysis did not change the slopes, but decreased the variance explained - all $\mathrm{CAM}$ and $\mathrm{C}_{4}$ plants were collected from lowland sites and heat tolerance was higher in CAM plants, and lower in the $\mathrm{C}_{4}$ plant than in $\mathrm{C}_{3}$ plants. $\mathrm{T}_{50}$ and $\mathrm{T}_{\text {Crit }}$ decreased by $0.26^{\circ} \mathrm{C}$ and $0.39^{\circ} \mathrm{C}$ per $100 \mathrm{~m}$, respectively $\left(0.28^{\circ} \mathrm{C}\right.$ and $0.41^{\circ} \mathrm{C}$ per $100 \mathrm{~m}$ when including non- $\mathrm{C}_{3}$ species $)$. The lapse rate across the study sites was $0.63^{\circ} \mathrm{C}$ decrease in mean annual temperature (MAT) per $100 \mathrm{~m}$ increase in elevation. 
Heat tolerance increased significantly with MAT $\left(\mathrm{F}_{1,150}=30.0\right.$ and 38.0 , for $\mathrm{T}_{50}$ and $\mathrm{T}_{\text {Crit }}$, respectively, $p$ $<0.001$ ) (Fig. 1). For every $1^{\circ} \mathrm{C}$ increase in MAT, $\mathrm{T}_{50}$ increased by $0.41^{\circ} \mathrm{C}$ and $\mathrm{T}_{\text {Crit }}$ increased by $0.60^{\circ} \mathrm{C}$. $\mathrm{T}_{50}$ and $\mathrm{T}_{\text {Crit }}$ also correlated significantly with the mean maximum temperature of the warmest month and with the mean minimum temperature of the coldest month (Fig. S4). The b parameter, the steepness of the decline in $\mathrm{F}_{\mathrm{v}} / \mathrm{F}_{\mathrm{m}}$ around $\mathrm{T}_{50}$, significantly decreased with elevation and increased with $\mathrm{MAT}$, so $\mathrm{F}_{\mathrm{v}} / \mathrm{F}_{\mathrm{m}}$ declined less steeply in cooler, higher elevation species than in lowland species. However, elevation and MAT only explained a small amount of variance in $\mathrm{b}\left(\mathrm{r}^{2}[?] 0.06\right)$.

Consistent with the patterns across species, within species there was a tendency for heat tolerance to decrease with elevation and increase with site temperature (irrespective whether minimum, mean, or maximum) (Fig. 2). Among lowland sites (between 0 and $200 \mathrm{~m}$ elevation, with MAT differences $<1 \operatorname{degC}$ ) patterns in heat tolerance with elevation and MAT were not consistent and the confidence intervals of the two values tended to overlap (Fig. 2). $\mathrm{T}_{50}$ and $\mathrm{T}_{\text {Crit }}$ decreased with elevation by 0.4 and $0.7 \mathrm{deg} \mathrm{C}$ per $100 \mathrm{~m}$, respectively, based on a regression weighted by elevation difference between sites - to reduce the weight of species measured at two lowland sites. $\mathrm{T}_{50}$ and $\mathrm{T}_{\text {Crit }}$ increased with site temperature by 0.9 and $1.5 \operatorname{deg} \mathrm{C}$ per $\operatorname{degC} \mathrm{MAT}$, respectively.

To enable comparison of heat tolerance among plant categories we standardized $T_{50}$ and $T_{\text {Crit }}$ to sea-level values using the trendlines in Fig. 1. Standardized $T_{50}$ and $T_{\text {Crit }}$ were not significantly different between native and non-native species, or between evergreen and deciduous species (Fig. S5). Gymnosperms tended to have moderately higher $\mathrm{T}_{50}$ than angiosperms $(p<0.1$, two-sample t-test) because of the high heat tolerance of three Zamiaspecies, but the sample size of gymnosperm species $(\mathrm{n}=5)$ was insufficient to draw meaningful biological conclusions from these apparent differences. For similar reasons, cycads (i.e., Zamiaspecies in our study), had higher $\mathrm{T}_{50}$ than lianas $(\mathrm{n}=6)$, shrubs (6), and trees (134), and higher $\mathrm{T}_{\text {Crit }}$ than lianas (Fig. S5). When including the CAM species Agave americanaand Furcraea cabuya, forbs had higher $\mathrm{T}_{50}$ than most other functional groups (not shown).

\section{Other traits}

LMA moderately increased with elevation $\left(\mathrm{F}_{1,127}=8.4, p=0.004, \mathrm{r}^{2}=0.06\right)$, as did leaf thickness $\left(\mathrm{F}_{1,127}=5.8\right.$, $p=0.017, \mathrm{r}^{2}$ adj $\left.=0.04\right)$ : Including the CAM plants in the analysis - all lowland plants with very high LMA and thick leaves - rendered these relationship non-significant. Leaf size decreased with elevation $\left(\mathrm{F}_{1,132}=10.0\right.$, $p=0.002, \mathrm{r}^{2}=0.07$ ), also when the CAM plants were included. As expected, opposite patterns were found with increasing site temperature. Other functional traits (density, LDMC, and leaf length: width ratio) did not change significantly with elevation. Likewise, there was no change in the thermal time constant $(\tau)$ with elevation. CAM plants fell on the extremes of the distributions of most functional traits, $\tau$, and heat tolerance, but there were insufficient $\mathrm{CAM}$ or $\mathrm{C}_{4}$ plants to develop separate models for species with different photosynthetic pathways. Analyses of trait correlations and phylogenetic controlled least square means models therefore focused on $\mathrm{C}_{3}$ plants alone.

\section{Phylogenetic and evolutionary patterns}

Heat tolerance vs taxon age

Heat tolerance was not related to the age of species estimated in Dicket al. (2013) (Fig. 3). Linear regressions between age and $\mathrm{T}_{50}$ and between age and $\mathrm{T}_{\text {Crit }}$ were not significant ( $p=0.10$ for both), suggesting no gradual trends. Likewise, species with warmer (Miocene) origins did not have systematically higher heat tolerance than species that emerged in the cooler recent (Pleistocene) past (two-sample t-test. $\mathrm{T}_{50}: \mathrm{t}=-1.5, p=0.19$. $\left.\mathrm{T}_{\text {Crit }}: \mathrm{t}=-1.5, p=0.25\right)$. Standardizing $\mathrm{T}_{50}$ and $\mathrm{T}_{\text {Crit }}$ to sea level values did not change these results. We also tested for trends of heat tolerance over longer timescales, using family age estimates from Wikström et al. (2001), who presented estimates for 29 of the families (representing 96 of the species) in the current study. As was the case for the data in Fig 3, there were no trends in heat tolerance with family ages (Fig. S6).

Phylogenetic patterns and trait correlations 
Fig. 4 shows the phylogenetic tree of the 144 identified species in our dataset, color coded by $\mathrm{T}_{50}$ standardized to sea level using the linear relationship with elevation shown in Fig. 1. There are some distinct clusters of related species with similar trait values, such as the high $\mathrm{T}_{50}$ values of the species of Zamia, the relatively high heat tolerance of the Moraceae (Ficus spp, Castilla elastica, Poulsenia armata, and Brosimum guianense ), and the relative low heat tolerance of the Annonaceae. However, the phylogenetic signal on $\mathrm{T}_{50}$ was not statistically significant with $\alpha$ of 0.05 (Blomdahl's $\mathrm{K}=0.11, P=0.06$; Pagel's $\lambda=0.51, P=0.08$ ), suggesting that across the phylogenetic tree related pairs of species were not significantly more similar to each other than random pairs. $\mathrm{T}_{\mathrm{Crit}}$ likewise did not show a significant phylogenetic signal $(\mathrm{K}=0.11, P=0.05 ; \lambda=0.17$, $P=0.99$. Fig. S7). In fact, the species with the highest and lowest $\mathrm{T}_{\mathrm{Crit}}$ values among native lowland trees both belong to the Urticaceae: $44.0^{\circ} \mathrm{C}$ for Pourouma bicolor , and $50.8^{\circ} \mathrm{C}$ for Cecropia longipes .

The leaf functional traits all had phylogenetic signals, with the exception of Blomdahl's $\mathrm{K}$ for leaf length. $\tau$ was also phylogenetically structured $(\mathrm{K}=0.18, P=0.022 ; \lambda=0.90, P<0.001)$.

\section{Heat tolerance in relation to leaf thermoregulation}

Regression models of $\mathrm{T}_{50}$ and $\mathrm{T}_{\text {Crit }}$ were consistently better (based on AIC) when they included elevation rather than any of the temperature metrics $\left(\mathrm{T}_{\mathrm{Min}}\right.$, MAT, or $\left.\mathrm{T}_{\mathrm{Max}}\right)$. Because temperature and elevation were tightly correlated, we did not include both in the same models. We tested the effects of various leaf traits associated with thermoregulation on heat tolerance. Leaf width did not correlate with $\mathrm{T}_{50}$ or $\mathrm{T}_{\text {Crit }}$. However, leaf area and elevation combined yielded a good model for $\mathrm{T}_{\mathrm{Crit}}\left(\mathrm{R}^{2}\right.$ adj $\left.=0.27, \mathrm{~F}_{2,118}=23.4, p<0.001\right)$. Very similar results were obtained for a model containing leaf length in addition to elevation, with $\mathrm{R}^{2}$ adj of 0.29 $\left(\mathrm{F}_{2,118}=25.5, p<0.001\right)$. Species with a higher $\tau$, i.e., species with leaves that take longer to heat and cool, had higher $\mathrm{T}_{\mathrm{Crit}}$ when accounting for elevation $\left(\mathrm{F}_{2,118}=22.6, p<0.001, \mathrm{R}^{2}{ }_{\text {adj }}=0.27\right)$, without an interaction effect of elevation $-\mathrm{T}_{\text {Crit }}$ was greater at low than at high elevation (Two-sample $\mathrm{t}$ test, $\mathrm{t}=6.27, P<0.001$ ), whereas $\tau$ did not differ between sites (Fig. 5). When substituting MAT for elevation $\tau$ also significantly affected $\mathrm{T}_{\text {Crit }}\left(\mathrm{F}_{2,118}=19.6, p<0.001, \mathrm{R}^{2}\right.$ adj $\left.=0.24\right)$. $\mathrm{T}_{50}$ and $\mathrm{b}$ were not affected by $\tau$, and elevation did not interact significantly with $\tau$ 's relationship with heat tolerance traits.

Heat tolerance in relation to leaf construction costs

For $\mathrm{T}_{50}$ the best model included LMA and an interaction between elevation and LMA, with an adjusted $\mathrm{R}^{2}$ of $0.30\left(\mathrm{~F}_{2,118}=26.11, P<0.001\right)$. The significant interaction term arose from a strong positive effect of LMA on $\mathrm{T}_{50}$ in lowland species that was not observed among mid-elevation and pre-montane species (Fig. 6). LDMC did not have a significant effect on $\mathrm{T}_{50}(p>0.1)$. For $\mathrm{T}_{\text {Crit }}$, neither LMA nor LDMC were significant predictors. LDMC had a weak, but significant effect on $\mathrm{b}$, when elevation was included in the model $\left(\mathrm{F}_{2,118}=5.2, p<0.01, \mathrm{R}^{2}\right.$ adj $\left.=0.07\right)$, with species with greater LDMC showing steeper declines in $\mathrm{F}_{\mathrm{v}} / \mathrm{F}_{\mathrm{m}}$ around $\mathrm{T}_{50}$. LMA had a moderate, but statistically significant effect on $\mathrm{b}\left(\mathrm{F}_{2,118}=7.6, p=0.007\right.$, $\left.\mathrm{R}_{\text {adj }}^{2}=0.05\right)$.

\section{Discussion}

We evaluated variation in heat tolerance of sun-exposed leaves among tropical forest plants in Panama and show that irreversible damage to leaves starts at temperatures about $10-15^{\circ} \mathrm{C}$ above current mean maximum temperatures of the warmest month, but only a few degrees above the highest leaf temperatures measured in the field (Doughty \& Goulden 2008; Krause et al. 2010; Rey-Sánchez et al. 2016; Slot et al. 2016). Heat tolerance of plants with $\mathrm{C}_{3}$ photosynthesis was lower than that of the CAM species Agave americana andFurcraea cabuya, but had wide ranges nonetheless, with $\mathrm{T}_{\text {Crit }}$ being more variable than $\mathrm{T}_{50}$. As hypothesized, interspecific variation in heat tolerance was underpinned by differences in elevation and associated ambient temperatures across sites, and related to differences in leaf functional traits associated with thermoregulation and leaf construction costs within sites, particularly among lowland species, while phylogeny played a smaller role.

Heat tolerance decreases with elevation

The decrease in heat tolerance with elevation and associated change in temperature is not a function of 
species turnover and was observed both across and within species. This trend is consistent with patterns along an elevation gradient in Colombia (Feeley et al . 2020a), and with trends in heat tolerance with mean annual or mean growing season temperature across latitudes (O'Sullivan et al. 2017; Zhuet al . 2018). The fact that elevation was a better predictor of heat tolerance than MAT or the mean maximum temperature of the warmest month may reflect greater accuracy of elevation than of temperature data, as the WorldClim temperature data is spatially gridded at ${ }^{\sim} 1 \mathrm{~km}^{2}$ resolution. $\mathrm{T}_{50}$ increased by $1.6^{\circ} \mathrm{C}$ from a mean of $48.5^{\circ} \mathrm{C}$ at Cerro Jefe to $50.1^{\circ} \mathrm{C}$ in Panama City, while MAT increased by $4.9^{\circ} \mathrm{C}$ from $22.1^{\circ} \mathrm{C}$ to $27.0^{\circ} \mathrm{C}$, with an average increase across sites of $0.4^{\circ} \mathrm{C}$ per ${ }^{\circ} \mathrm{C}$ MAT. Thus, while there is a clear adjustment to temperature along this gradient, the thermal safety margin based on MAT - i.e., the difference between MAT and $\mathrm{T}_{50}$ - decreases with increasing growth temperature and is smallest in the already relatively hot lowlands.

The $0.4^{\circ} \mathrm{C}$ increase in $\mathrm{T}_{50}$ per ${ }^{\circ} \mathrm{C}$ change in MAT was comparable to the $0.38^{\circ} \mathrm{C}$ increase in $\mathrm{T}_{50}$ of $\mathrm{F}_{0}$ rise per ${ }^{\circ} \mathrm{C}$ mean temperature of the warmest month in the global dataset by O'Sullivan et al . (2017). However, along the tropical elevation gradient studied by Feeley et al . (2020a), $\mathrm{T}_{50}$ increased by only $0.08^{\circ} \mathrm{C}{ }^{\circ} \mathrm{C}^{-1} \mathrm{MAT}$. One possible reason for the strong response of heat tolerance to local temperature compared to Feeley et al . (2020a) is the relatively narrow ranges in environmental conditions in the current study. Heat tolerance can increase with drought, cold, and other stressors (Sapper 1935; Kappen 1964; Ladjal et al . 2000; Sastryet al . 2018), as mild conditioning to other stressors may increase antioxidant scavenging (Gill \& Tuteja 2010) that would also benefit heat tolerance. $T_{50}$ of the warmest site in Feeley et al . (2020a) was comparable to that observed in the current study, so it is the cooler sites in Feeley et al . that have relatively high heat tolerance. The coolest site in Feeley et al . (2020a) is at almost $3000 \mathrm{~m}$ asl. At such elevation UV radiation can be strong, potentially causing cellular damage against which antioxidant activity can provide protection (Foyer et al . 1994). At another high-UV site in Colombia, $\mathrm{T}_{50}$ values averaged $49.2^{\circ} \mathrm{C}$ (Leon-Garcia \& Lasso 2019), despite mean annual temperatures of $<10^{\circ} \mathrm{C}$, supporting the notion that high heat tolerance is not solely associated with high growing temperatures. The growing conditions at our pre-montane sites are favorable for most plants, and the elevation gradient represents a temperature gradient not confounded by gradients in other stressors such as UV radiation, cold, or drought.

Three species were collected both in lowland and in pre-montane forest. Of these, two showed the expected pattern in heat tolerance with elevation and temperature; Aspidosperma spruceanum — primarily a lowland species - and Posoqueria latifolia — a species widely distributed across lowland and pre-montane sites. The species that did not show any trends was Podocarpus guatemalensis, a species of lower montane regions. This species maintained comparatively low heat tolerance when it was growing under warm lowland conditions. This is consistent with observations that while heat tolerance can be downregulated in response to (seasonal) low temperature (e.g., Sastry \& Barua 2017; Zhu et al . 2018), there is limited evidence for the upregulation of heat tolerance in response to warming (but see Drakeet al . 2018), especially of tropical species (Krause et al . 2010, 2013).

\section{Limited phylogenetic patterns in physiologically plastic traits}

Our study included species belonging to families that differ widely in their earliest occurrence in evolutionary history, and therefore in climate regimes they have experienced throughout their existence. For example, Fabaceae have existed in the Neotropics for at least 58 million years (Wing et al . 2009) and their relative abundance did not decrease during the Paleocene-Eocene Thermal Maximum ( $\sim 56 \mathrm{Ma})$ when temperatures in the tropics rapidly rose by 3 to $5^{\circ} \mathrm{C}$ (Jaramillo et al . 2010). We found no evidence, however, that Fabaceae or other relatively old families have greater heat tolerance and are therefore better equipped for end-of-century conditions than taxa that emerged more recently. Knight \& Ackerly (2003) found that congeneric species of Californian coastal and desert ecosystems had very similar $\mathrm{T}_{50}$ when grown in a common environment, despite maximum temperatures being $10^{\circ} \mathrm{C}$ greater in the desert than in the coastal region. The lack of convergent adaptation of heat tolerance suggested high plasticity in heat tolerance instead (Knight \& Ackerly 2003). Across the phylogenetic tree there were some distinct clusters, indicating similarity in heat tolerance among sister species; overall the phylogenetic signal in heat tolerance was weak, however, in accordance with other recent studies (Lancaster \& Humphries 2020; Perez \& Feeley 2020b). The predominance of plasticity 
over evolutionary legacies is consistent with the plasticity in the temperature relations of other aspects of metabolism in trees from the aseasonal lowland tropics, such as the convergence of the optimum temperature for photosynthesis on local mean temperatures in diverse forest communities (Slot \& Winter 2017a), and acclimation of photosynthesis (Slot \& Winter 2017b) and leaf respiration (Cheesman \& Winter 2013; Slot et al . 2014) to experimental warming.

\section{Large-leaved species and slow-cooling species have higher heat tolerance}

Leaf width is an important driver of leaf temperature (Leigh et al . 2017; Fauset et al . 2018), as is overall leaf size (Leighet al . 2017), with wide and large leaves warming up more than narrow and small ones under similar conditions. Leaf width did not affect heat tolerance, but $\mathrm{T}_{\text {Crit }}$ increased with leaf size. This supports the idea that species with a large boundary layer that are more likely to experience high temperatures should have higher tolerance to those temperatures. Indeed, Perez \& Feeley (2020a) recently showed that $\mathrm{T}_{50}$ scaled with the highest measured leaf temperature among 19 species in the Fairchild Tropical Botanical Garden in Florida.

Heat tolerance - specifically $\mathrm{T}_{\text {Crit }}$, the temperature associated with the onset of thermal damage - increases with the estimated thermal time constant $\tau$, while it was hypothesized to decrease. Species with low $\tau$ can rapidly heat up, so they were expected to have a selective advantage of high heat tolerance. However, species with low $\tau$ also cool down again quickly, so while they may experience higher temperatures, these high temperatures are unlikely to be sustained for long periods of time. The protocol we used to determine heat tolerance involves 15-minute exposure to set temperatures, and it is the exposure to 15 minutes of $\mathrm{T}_{\text {Crit }}$ that causes the initiation of irreversible heat damage. Species with high $\tau$ are more buffered against temperature fluctuations and thus more likely to experience a temperature for 15 minutes continuously than species with low $\tau$, even if the peak temperatures are lower than those low- $\tau$ species experience. We could not assess whether high $\tau$ leaves in the current study indeed experienced more sustained high temperatures and low $\tau$ leaves higher but shorter peak temperatures, nor whether large-leaved species were consistently warmer than small-leaved species, as high-resolution, long-term monitoring of leaf temperatures of 147 tropical forest species was not feasible. New developments in wireless sensor networks and infrared thermometry provide avenues for detailed monitoring of canopy microclimates and leaf temperatures in the near future (e.g., Egea et al . 2017; Jin et al . 2018; Websteret al . 2018), to determine variation in the thermal safety margins across species, and their underlying morphological and physiological traits.

\section{Heat tolerance in relation to leaf construction costs}

$\mathrm{T}_{50}$ scaled with LMA, supporting the hypothesis that heat tolerance increases with increasing construction costs of the leaves. This relationship was strong among lowland species, but the (considerably smaller) variation in $\mathrm{T}_{50}$ among mid-elevation and pre-montane species was driven by other, unidentified factors. Previous links between heat tolerance and leaf cost traits LMA and LDMC were obtained at sites with considerable temperature seasonality (e.g., Knight \& Ackerly 2003; Sastry \& Barua 2017). In the current study temperature seasonality was minimal, with the difference in mean temperature between the hottest and the coolest month $[?] 2.0^{\circ} \mathrm{C}$ at all sites, including the lowland sites. In these lowland forests LMA correlates strongly with leaf lifespan (Kitajima \& Poorter 2010). While greater leaf lifespan does not significantly increase the likelihood of exposure to higher air temperature, leaf temperature may be considerably higher in the dry season, when incoming solar radiation at the canopy level is greater (Rey-Sánchez et al . 2016). If dry-season water deficit forces stomatal closure, limited transpirational cooling leads to further increases in leaf temperature, especially in the warmer lowlands with prolonged dry seasons. Increased heat tolerance may thus be advantageous for leaves that persist through the dry season. Evergreen species did not have higher heat tolerance than deciduous species in a subset of 99 species for which this information was known (Fig. S5), but more detailed information on leaf phenology may be required to evaluate the effects of potentially high dry season leaf temperatures.

Heat tolerance metrics, their relations, and identifying large-scale patterns

Tiwari et al . (2020) recently showed that the higher $\mathrm{T}_{\text {Crit }}$ was among seven Amazonian tree species, the 
steeper the decrease in $\mathrm{F}_{\mathrm{v}} / \mathrm{F}_{\mathrm{m}}$ above $\mathrm{T}_{\text {Crit }}$. We found the same pattern across the 147 species in our study. As $\mathrm{T}_{\text {Crit }}$ increased in our study, the b parameter became more negative $\left(\mathrm{r}^{2}=0.29\right)$. $\mathrm{T}_{50}$ of lowland tropical species appears to be close to a hard, upper limit, as suggested by the fact that growth at elevated temperature does not significantly increase $T_{50}$ (Krauseet al . 2010, 2013). Indeed, $T_{50}$ of tropical plants tends to be less variable than $\mathrm{T}_{\text {Crit }}$ (Tiwariet al. 2020; Perez \& Feeley 2020a; current study). This suggests that when plants can prevent irreversible damage up to a higher temperature (i.e., have a higher $T_{\text {Crit }}$ ) the decrease in $F_{v} / F_{m}$ is necessarily steeper. This also means that across a temperature gradient, $\mathrm{T}_{\text {Crit }}$ increases more steeply with temperature than $\mathrm{T}_{50}$. Interspecific variation in $\mathrm{b}$ also explains why $\mathrm{T}_{50}$ and $\mathrm{T}_{\text {Crit }}$, although correlated, did not scale equally with other leaf traits. For example, we found a significant relationship between $\mathrm{T}_{50}$ and LMA among lowland plants, but not between $\mathrm{T}_{\text {Crit }}$ and LMA, because b correlated with LMA in such a way that the slope of the $\mathrm{T}_{\text {Crit }}-\mathrm{LMA}$ relationship was reduced relative to the $\mathrm{T}_{50}$-LMA slope.

In 1935, Sapper (1935) wrote that since the pioneering work by Sachs (1864) various studies had been conducted to investigate plant heat tolerance, but that systematic comparisons are complicated by the alltoo-different methodologies used. This remains true 85 years later (Geange et al. 2020). A recent study (Lancaster \& Humpreys 2020) compiled heat tolerance data from across the plant kingdom, but combined metrics with fundamentally different meanings, such as $\mathrm{T}_{50}$ of $\mathrm{F}_{\mathrm{v}} / \mathrm{F}_{\mathrm{m}}$ as defined in the current study (using data from e.g., Slot et al . 2018), $\mathrm{T}_{50}$ of $\mathrm{F}_{0}$ rise (e.g., Zhu et al . 2018), $\mathrm{T}_{\text {Crit }}$ of $\mathrm{F}_{0}$ rise (Marias et al . 2016), $\mathrm{T}_{\mathrm{Max}}$ of dark respiration (e.g., O'Sullivanet al . 2017), and heat tolerance based on electrolyte leakage (e.g., Nobel \& Smith 1983). Identifying reliable, general patterns of thermal tolerance across environmental gradients thus remains challenging, and more studies are needed using consistent methodology (Geange et al. 2020). Here we used $>110$ lowland species - the largest dataset on heat tolerance of lowland tropical forest plants to date - and almost 40 mid-elevation to pre-montane species, measured with a now commonly used protocol (Krause et al. 2010). We show that $30 \%$ of the heat tolerance variation across a phylogenetically and functionally diverse range of species could be explained by elevation and LMA alone. Site elevation is readily available, and LMA is one of the best represented traits in the TRY database (Kattge et al . 2020), making this a useful predictor, at least for the species-rich and understudied lowland tropics - at higher elevation neither LMA, nor indeed any of the tested traits was a strong predictor of heat tolerance. Remaining variation is likely explained in part by variation in microclimate, which has been shown to have strong effects on maximum leaf temperatures (Fauset et al. 2018), and heat tolerance (Curtis et al. 2016; Perez \& Feeley 2020a); differences in preconditioning to mild stressors that caused upregulation in antioxidant activity; and variation in other aspects that may protect leaves against heat damage, such as the capacity for isoprene emission, which is associated with higher maximum temperature for carbon fixation among tropical forest species (Taylor et al . 2019).

Tropical forests are sensitive to rising temperatures. Warming decreases net carbon uptake (Clark et al . 2003; Sullivan et al . 2020), results in shifts in species composition (e.g., Fadrique et al . 2018; Feeley et al . 2020b), and exacerbates climate extremes (Rifai et al . 2019) and the risk of associated mortality. Due to the increased frequency of extreme events $\mathrm{T}_{\text {Crit }}$ may already be exceeded occasionally in forests in the southern Amazon (Tiwari et al . 2020). We showed that lowland forests in Panama are operating closer to their critical upper temperature thresholds than pre-montane forests, but that in both ecosystems species differ considerably in their proximity to critical thresholds. To properly determine thermal safety margins detailed information is needed on variation in leaf temperature dynamics among co-occurring species, and predicting future safety margins further requires understanding of the plasticity of heat tolerance; upregulation of heat tolerance appears limited, but this needs to be tested for more tropical forest species.

\section{Conflicting interests}

None declared

\section{Author contributions}

MS and KW designed the study; DC, MS, JA and AV collected the samples; JA and AV identified species, helped locate target species, and provided logistical support in the field and lab; DC measured fluorescence 
and leaf traits; MS and DC performed the analyses; SM calculated thermal time constants and interpreted their results; MS wrote the manuscript with contributions of DC, KW, and SM.

\section{Orcid}

Martijn Slot: https://orcid.org/0000-0002-5558-1792

Sean T. Michaletz: https://orcid.org/0000-0003-2158-6525

Klaus Winter: https://orcid.org/0000-0002-0448-2807

\section{References}

Blomberg, S.P., Garland Jr, T., Ives, A.R. (2003) Testing for phylogenetic signal in comparative data: behavioral traits are more labile. Evolution 57 , 717-745.

Cheesman, A.W., Winter, K. (2013) Elevated night-time temperatures increase growth in seedlings of two tropical pioneer tree species. New Phytologist , 197 , 1185-1192.

Clark, D.A., Piper, S.C., Keeling, C.D., Clark, D.B. (2003) Tropical rain forest tree growth and atmospheric carbon dynamics linked to interannual temperature variation during 1984-2000. Proceedings of the National Academy of Sciences , $100,5852-5857$.

Coley, P.D. (1987) Interspecific variation in plant anti-herbivore properties: the role of habitat quality and rate of disturbance. New Phytologist, $106,251-263$.

Curtis, E.M., Gollan, J., Murray, B.R., Leigh, A. (2016) Native microhabitats better predict tolerance to warming than latitudinal macro-climatic variables in arid-zone plants. Journal of Biogeography , 43 , 1156-1165.

Dick, C.W., Lewis, S.L., Maslin, M., Bermingham, E. (2013) Neogene origins and implied warmth tolerance of Amazon tree species.Ecology and Evolution , 3 , 162-169.

Doughty, C.E., Goulden, M.L. (2008) Are tropical forests near a high temperature threshold? Journal of Geophysical Research: Biogeosciences, 113 (G1).

Drake, J.E., Tjoelker, M.G., Varhammar, A., Medlyn, B.E., Reich, P.B., Leigh, A., Pfautsch, S., Blackman, C.J., Lopez, R., Aspinwall, M.J., Crous, K.Y. (2018) Trees tolerate an extreme heatwave via sustained transpirational cooling and increased leaf thermal tolerance. Global Change Biology , 24 , 2390-2402.

Duarte, H., Tejedo, M., Katzenberger, M., Marangoni, F., Baldo, D., Beltran, J.F., Marti, D.A., RichterBoix, A., Gonzalez-Voyer, A. (2012) Can amphibians take the heat? Vulnerability to climate warming in subtropical and temperate larval amphibian communities. Global Change Biology , 18 , 412-421.

Egea, G., Padilla-Diaz, C.M., Martinez-Guanter, J., Fernandez, J.E., Perez-Ruiz, M. (2017) Assessing a crop water stress index derived from aerial thermal imaging and infrared thermometry in super-high density olive orchards. Agricultural Water Management, 187, 210-221.

Fadrique, B., Baez, S., Duque, A., Malizia, A., Blundo, C., Carilla, J., Osinaga-Acosta, O., Malizia, L., Silman, M., Farfan-Rios, W, et al . (2018) Widespread but heterogeneous responses of Andean forests to climate change. Nature, 564, 207-212.

Fauset, S., Freitas, H.C., Galbraith, D.R., Sullivan, M.J., Aidar, M.P., Joly, C.A., Phillips, O.L., Vieira, S.A., Gloor, M.U. (2018) Differences in leaf thermoregulation and water use strategies between three co-occurring Atlantic forest tree species. Plant, Cell \& Environment , 41, 1618-1631.

Feeley, K.J., Martinez-Villa, J., Perez, T.M., Silva Duque, A., Trivino Gonzalez, D., Duque, A. (2020a) The thermal tolerances, distributions, and performances of tropical montane tree species. Frontiers in Forest and Global Change, 3, 25. 
Feeley, K.J., Bravo-Avila, C., Fadrique, B., Perez, T.M., Zuleta, D. (2020b) Climate-driven changes in the composition of New World plant communities. Nature Climate Change, 10 , 1062.

Fick, S.E., Hijmans, R.J. (2017) WorldClim 2: new 1km spatial resolution climate surfaces for global land areas. International Journal of Climatology , 37 , 4302-4315.

Foyer, C.H., Lelandais, M., Kunert, K.J. (1994) Photooxidative stress in plants. Physiologia Plantarum, 92 , 696-717.

Franken, O., Huizinga, M., Ellers, J., Berg, M.P. (2018) Heated communities: large inter-and intraspecific variation in heat tolerance across trophic levels of a soil arthropod community. Oecologia ,186 , 311-322.

Garcia-Robledo, C., Kuprewicz, E.K., Staines, C.L., Erwin, T.L., Kress, W.J. (2016) Limited tolerance by insects to high temperatures across tropical elevational gradients and the implications of global warming for extinction. Proceedings of the National Academy of Sciences ,113, 680-685.

Geange, S.R., Arnold, P.A., Catling, A.A., Coast, O., Cook, A.M., Gowland, K.M., Leigh, A., Notarnicola, R.F., Posch, B.C., Venn, S.E., Zhu, L. (2020) The thermal tolerance of photosynthetic tissues: a global systematic review and agenda for future research. New Phytologist. In press. doi: https://doi.org/10.1111/nph.17052

Gill, S.S., Tuteja, N. (2010) Reactive oxygen species and antioxidant machinery in abiotic stress tolerance in crop plants. Plant Physiology and Biochemistry , 48 , 909-930.

Goulden M.L., Miller S.D., da Rocha H.R., Menton M.C., de Freitas H.C., Figueira A.M.E.S., de Sousa C.A.D. (2004) Diel and seasonal patterns of tropical forest $\mathrm{CO}_{2}$ exchange. Ecological Applications 14, $42-54$

Jaramillo, C., Ochoa, D., Contreras, L., Pagani, M., Carvajal-Ortiz, H., Pratt, L.M., Krishnan, S., Cardona, A., Romero, M., Quiroz, L., Rodriguez, G. (2010) Effects of rapid global warming at the Paleocene-Eocene boundary on neotropical vegetation. Science ,330, 957-961.

Jin, J., Wang, Y., Jiang, H., Chen, X. (2018) Evaluation of microclimatic detection by a wireless sensor network in forest ecosystems. Scientific Reports , 8 , 1-9.

Jin, Y., Qian, H. (2019) V. PhyloMaker: an R package that can generate very large phylogenies for vascular plants. Ecography ,42, 1353-1359.

Jones, H.G. (2013) Plants and microclimate: a quantitative approach to environmental plant physiology. Cambridge University Press.

Kappen, L. (1964) Untersuchungen uber den Jahreslauf der Frost-, Hitze-und Austrocknungsresistenz von Sporophyten einheimischer Polypodiaceen (Filicinae). Flora, 155, 123-166.

Kattge, J., Bonisch, G., Diaz, S., Lavorel, S., Prentice, I.C., Leadley, P., Tautenhahn, S., Werner, G.D., Aakala, T., Abedi, M. et al . (2020) TRY plant trait database-enhanced coverage and open access. Global Change Biology , 26 , 119-188.

Kitajima, K., Poorter, L. (2010) Tissue-level leaf toughness, but not lamina thickness, predicts sapling leaf lifespan and shade tolerance of tropical tree species. New Phytologist , 186 , 708-721.

Knight, C.A., Ackerly, D.D. (2003) Evolution and plasticity of photosynthetic thermal tolerance, specific leaf area and leaf size: congeneric species from desert and coastal environments. New Phytologist, 160 , $337-347$.

Kosugi Y, Takanashi S, Ohkubo S, Matsuo N, Tani M, Mitani T, Tsutsumi D, Nik AR (2008) $\mathrm{CO}_{2}$ exchange of a tropical rainforest at Pasoh in peninsular Malaysia. Agricultural and Forest Meteorology 148, 439-452

Krause, G.H., Cheesman, A.W., Winter, K., Krause, B., Virgo, A. (2013) Thermal tolerance, net $\mathrm{CO}_{2}$ exchange and growth of a tropical tree species, Ficus insipida, cultivated at elevated daytime and nighttime temperatures. Journal of Plant Physiology ,170 , 822-827 
Krause, G.H., Winter, K., Krause, B., Jahns, P., Garcia, M., Aranda, J., Virgo, A. (2010) High-temperature tolerance of a tropical tree,Ficus insipida: methodological reassessment and climate change considerations. Functional Plant Biology, 37 , 890-900.

Krause, G.H., Winter, K., Krause, B., Virgo, A. (2016) Protection by light against heat stress in leaves of tropical crassulacean acid metabolism plants containing high acid levels. Functional Plant Biology , 43 , 1061-1069

Ladjal, M., Epron, D., Ducrey, M. (2000) Effects of drought preconditioning on thermotolerance of photosystemII and susceptibility of photosynthesis to heat stress in cedar seedlings. Tree Physiology , 20 , $1235-1241$

Lancaster, L.T., Humphreys, A.M. (2020) Global variation in the thermal tolerances of plants. Proceedings of the National Academy of Sciences , 117, 13580-13587

Leigh, A., Sevanto, S., Close, J.D., Nicotra, A.B. (2017) The influence of leaf size and shape on leaf thermal dynamics: does theory hold up under natural conditions? Plant, Cell $\mathscr{6} 3$ Environment ,40 , 237-248.

Leon-Garcia, I.V., Lasso, E. (2019) High heat tolerance in plants from the Andean highlands: Implications for paramos in a warmer world. PloS one, 14, e0224218.

Marias, D.E., Meinzer, F.C., Woodruff, D.R., McCulloh, K.A. (2016) Thermotolerance and heat stress responses of Douglas-fir and ponderosa pine seedling populations from contrasting climates. Tree Physiology , 37, 301-315

Michaletz, S.T., Weiser, M.D., Zhou, J., Kaspari, M., Helliker, B.R., Enquist, B.J. (2015) Plant thermoregulation: energetics, trait-environment interactions, and carbon economics. Trends in Ecology 83 Evolution, $30,714-724$.

Michaletz, S.T., Weiser, M.D., McDowell, N.G., Zhou, J., Kaspari, M., Helliker, B.R., Enquist, B.J. (2016) The energetic and carbon economic origins of leaf thermoregulation. Nature Plants , 2 , 16129.

Nardini, A., Peda, G., Rocca, N.L. (2012) Trade-offs between leaf hydraulic capacity and drought vulnerability: morpho-anatomical bases, carbon costs and ecological consequences. New Phytologist ,196 , 788-798.

Nobel, P.S., Smith, S.D. (1983) High and low temperature tolerances and their relationships to distribution of agaves. Plant, Cell \& Environment, 6 , 711-719.

O'Sullivan, O.S., Heskel, M.A., Reich, P.B., Tjoelker, M.G., Weerasinghe, L.K., Penillard, A., Zhu, L., Egerton, J.J., Bloomfield, K.J., Creek, D., Bahar, N.H., Griffin, K.L., Hurry, V., Meir, P., Turnbull, M.H., Atkin, O.K. (2017) Thermal limits of leaf metabolism across biomes. Global Change Biology , 23 , 209-223.

Padfield, D., Matheson, G. (2018) nls.multstart: Robust Non-Linear Regression using AIC Scores. R package version 1.0.0 . https://CRAN.R-project.org/package=nls.multstart

Padfield, D., Lowe, C., Buckling, A., Ffrench-Constant, R., Student Research Team, Jennings, S., Shelley, F., Olafsson, J.S., Yvon-Durocher, G. (2017) Metabolic compensation constrains the temperature dependence of gross primary production. Ecology Letters , 20 , 1250-1260.

Pagel, M. (1999) Inferring the historical patterns of biological evolution. Nature, 401, 877-884.

Perez, T.M., Feeley, K.J. (2020a) Photosynthetic heat tolerances and extreme leaf temperatures. Functional Ecology , 34, 2236-2245.

Perez, T.M., Feeley, K.J. (2020b) Weak phylogenetic and climatic signals in plant heat tolerance. Journal of Biogeography. In press. doi: https://doi.org/10.1111/jbi.13984

R Core Team (2019). R: A language and environment for statistical computing. R Foundation for Statistical Computing, Vienna, Austria. URL https://www.R-project.org/. 
Rey-Sanchez, C., Slot, M., Posada, J.M., Kitajima, K. (2016) Spatial and seasonal variation of leaf temperature within the canopy of a tropical forest. Climate Research , 71, 75-89.

Revell, L.J. (2010) Phylogenetic signal and linear regression on species data. Methods in Ecology and Evolution 1, 319-329.

Revell, L.J. (2012) Phytools: an R package for phylogenetic comparative biology (and other things). Methods in Ecology and Evolution ,3 , 217-223.

Rifai, S.W., Li, S., Malhi, Y. (2019) Coupling of El Nino events and long-term warming leads to pervasive climate extremes in the terrestrial tropics. Environmental Research Letters , 14 , p.105002.

Sachs, J. (1864) Uber die obere Temperaturgranze der Vegetation.Flora , 47 , 5-12, 24-29, 33-39, 65-75.

Sapper, I. (1935) Versuche zur Hitzeresistenz der Pflanzen.Planta, 518-556.

Sastry, A., Barua, D. (2017) Leaf thermotolerance in tropical trees from a seasonally dry climate varies along the slow-fast resource acquisition spectrum. Scientific Reports , 7, 11246.

Sastry, A., Guha, A., Barua, D. (2018) Leaf thermotolerance in dry tropical forest tree species: relationships with leaf traits and effects of drought. AoB Plants, 10 , plx070.

Scheffer, M. (2009) Critical transitions in nature and society (Vol. 16). Princeton University Press.

Slot, M., Rey-Sanchez, C., Gerber, S., Lichstein, J.W., Winter, K., Kitajima, K. (2014) Thermal acclimation of leaf respiration of tropical trees and lianas: response to experimental canopy warming, and consequences for tropical forest carbon balance. Global Change Biology , 20 , 2915-2926.

Slot M, Garcia MN, Winter K (2016) Temperature response of $\mathrm{CO}_{2}$ exchange in three tropical tree species. Functional Plant Biology 43, 468-478

Slot, M., Winter, K. (2017a) In situ temperature response of photosynthesis of 42 tree and liana species in the canopy of two Panamanian lowland tropical forests with contrasting rainfall regime.New Phytologist , 214, 1103-1117.

Slot, M., Winter, K. (2017b) Photosynthetic acclimation to warming in tropical forest tree seedlings. Journal of Experimental Botany ,68, 2275-2284.

Slot, M., Krause, G.H., Krause, B., Hernandez, G.G., Winter, K. (2019) Photosynthetic heat tolerance of shade and sun leaves of three tropical tree species. Photosynthesis Research , 141 , 119-130.

Smith, S.A., Brown, J.W. (2018) Constructing a broadly inclusive seed plant phylogeny. American Journal of Botany, 105, 302-314.

Sullivan, M.J., Lewis, S.L., Affum-Baffoe, K., Castilho, C., Costa, F., Sanchez, A.C., Ewango, C.E., Hubau, W., Marimon, B., Monteagudo-Mendoza, A. et al . (2020) Long-term thermal sensitivity of Earth's tropical forests. Science, $\mathbf{3 6 8}, 869-874$.

Taylor, T.C., Smith, M.N., Slot, M., Feeley, K.J. (2019) The capacity to emit isoprene differentiates the photosynthetic temperature responses of tropical plant species. Plant, Cell \& Environment , 42 , 24482457.

Tiwari, R., Gloor, E., da Cruz, W.J.A., Schwantes Marimon, B., Marimon-Junior, B.H., Reis, S.M., de Souza, I.A., Krause, H.G., Slot, M., Winter, K., et al. (2020) Photosynthetic quantum efficiency in southeastern Amazonian trees may be already affected by climate change. Plant, Cell $\mathscr{E}$ Environment. In press. doi: https://doi.org/10.1111/pce.13770.

Vogel, S. (2009) Leaves in the lowest and highest winds: temperature, force and shape. New Phytologist, $183,13-26$. 
Webster, C., Westoby, M., Rutter, N. and Jonas, T. (2018) Three-dimensional thermal characterization of forest canopies using UAV photogrammetry. Remote Sensing of Environment, 209 , 835-847.

Wikstrom, N., Savolainen, V., Chase, M.W. (2001) Evolution of the angiosperms: calibrating the family tree. Proceedings of the Royal Society of London. Series B: Biological Sciences , 268 , 2211-2220.

Wing, S.L., Herrera, F., Jaramillo, C.A., Gomez-Navarro, C., Wilf, P. and Labandeira, C.C. (2009) Late Paleocene fossils from the Cerrejon Formation, Colombia, are the earliest record of Neotropical rainforest.Proceedings of the National Academy of Sciences , 106 , 18627-18632.

Zanne, A.E., Tank, D.C., Cornwell, W.K., Eastman, J.M., Smith, S.A., FitzJohn, R.G., McGlinn, D.J., O'Meara, B.C., Moles, A.T., Reich, P.B., Royer, D.L. (2014) Three keys to the radiation of angiosperms into freezing environments. Nature, 506, 89-92.

Zhu, L., Bloomfield, K.J., Hocart, C.H., Egerton, J.J., O'Sullivan, O.S., Penillard, A., Weerasinghe, L.K., Atkin, O.K. (2018) Plasticity of photosynthetic heat tolerance in plants adapted to thermally contrasting biomes. Plant, Cell \& Environment, 41, 1251-1262.

Zotz G, Harris G, Koniger M,Winter K (1995) High rates of photosynthesis in the tropical pioneer tree, Ficus insipida Willd. Flora 190, 265-272

\section{Supporting information}

Table S1 . Comparison of monitored and WorldClim mean annual temperatures.

Table S2 . Species list with heat tolerance data.

Fig. S1 . Collection sites plotted on a map of mean maximum temperatures in Panama.

Fig. S2 . Heat tolerance through the seasons of the sample period

Fig. S3. Distribution of $\mathrm{T}_{50}$ and $\mathrm{T}_{\text {Crit }}$ for lowland vs non-lowland sites.

Fig. S4.$T_{50}$ and $T_{\text {Crit }}$ as a function of minimum and maximum temperatures of study sites.

Fig. S5 . Standardized $\mathrm{T}_{50}$ and $\mathrm{T}_{\mathrm{Crit}}$ compared across categorical variables.

Fig. S6 . T 50 versus estimated family 'ages'.

Fig. S7 . Phylogenetic tree of the study species color-coded by $\mathrm{T}_{\text {Crit }}$

Figure legends

Fig. 1. Thermal thresholds $T_{50}(a, b)$ and $T_{\text {Crit }}(c, d)$ as a function of elevation and mean annual temperature for 150 tropical species. Values for CAM plants and $\mathrm{C}_{4}$ plants are indicated in red and blue, respectively. Black and red lines and $\mathrm{r}^{2}$ values indicate linear regressions for the full dataset and for $\mathrm{C}_{3}$ plants only, respectively. For $\mathrm{C}_{3}$ : a) $\mathrm{T}_{50}=50.4-0.0026$ x Elevation (m asl). b) $\mathrm{T}_{50}=39.3+0.41 \times$ MAT. c) $\mathrm{T}_{\text {Crit }}=47.4-$ $0.0039 \times$ Elevation. d) $\mathrm{T}_{\text {Crit }}=31.2+0.60 \mathrm{xMAT}$.

Fig 2. Thermal thresholds $T_{50}$ and $T_{\text {Crit }}$ in relation to elevation for species that were measured at two contrasting elevations. Error bars indicate $95 \%$ confidence intervals approximated as $\mathrm{T}_{50}+-1.96 \mathrm{x}$ standard error of $\mathrm{T}_{50}$. 1. Posoqueria latifolia , 2. Aspidosperma spruceanum, 3. Protium panamense, 4.Ceiba pentandra , 5. Coccoloba uvifera, 6. Podocarpus guatemalensis, 7. Guatteria lucens .

Fig 3. Relationship between thermal thresholds $\mathrm{T}_{50}$ and $\mathrm{T}_{\mathrm{Crit}}$ and species 'ages'. Gray diamonds show data for Chrysophyllum cainito, a sister species of C. argentum dated in Dick et al . (2013). Species names in blue represent Pleistocene; green, Pliocene; red, Miocene.

Fig. 4. Phylogenetic tree of study species with branches color coded by the value of $\mathrm{T}_{50}$ standardized to sea level. Red and blue arrows indicate CAM-exhibiting species and $\mathrm{C}_{4}$ species, respectively. Black nodes represent polytomies. 
Fig. 5 . Leaf critical temperature $\left(\mathrm{T}_{\text {Crit }}\right)$ as a function of the estimated thermal time constant $(\log \tau)$ and elevation. Solid and dashed lines indicate significant and non-significant correlations for lowland and non-lowland data, respectively. Shaded areas indicate $95 \%$ confidence intervals of the predictions. Boxplots illustrate lowland (open bars) vs non-lowland (mid-elevation and pre-montane) sites (closed bars). ${ }^{* *} P$ $<0.001)$.

Fig. 6. $\mathrm{T}_{50}$ as a function of leaf mass per area (LMA) and elevation. Solid and dashed lines indicate significant and non-significant correlations for lowland and non-lowland data, respectively. Shaded areas indicate $95 \%$ confidence intervals of the predictions. Boxplots illustrate lowland (open bars) vs non-lowland (mid-elevation and pre-montane) sites (closed bars). ${ }^{*} P<0.05,{ }^{* *} P<0.01$ ).

Table 1. Geographic and temperature data for the sample sites. $T_{\text {Min }}$ is the mean minimum temperature of the coolest month, MAT is mean annual temperature and $\mathrm{T}_{\mathrm{Max}}$ is the mean maximum temperature of the warmest month.

\begin{tabular}{lllll}
\hline Region & Site & Lat. $\left({ }^{\circ} \mathrm{N}\right)$ & Long. $\left({ }^{\circ} \mathrm{W}\right)$ & Eleva \\
\hline Panama City & Ancón | Albrook | Clayton | Parque Natural Metropolitano & 8.9637 & 79.5458 & 25 \\
Parque Nacional Soberania & Gamboa & 9.1240 & 79.6965 & 44 \\
& Barro Colorado Island & 9.1165 & 79.6965 & 54 \\
Colón & Parque Nacional San Lorenzo & 9.3640 & 79.9593 & 62 \\
& Punta Galeta & 9.4008 & 79.8697 & 2 \\
& Santa Rita Arriba & 9.3395 & 79.6792 & 200 \\
Panama Oeste & Parque Nacional Altos de Campana & 8.6875 & 79.9875 & 526 \\
& Arraiján & 8.9394 & 79.6423 & 129 \\
Coclé & Cerro los Cañones & 8.9236 & 80.0358 & 300 \\
Chepo district & Penonomé & 8.5503 & 80.3547 & 99 \\
& Cerro Jefe & 9.2319 & 79.3954 & 750 \\
& Cerro Azul & 9.2347 & 79.3514 & 650 \\
& Carretera Llano-Cartí & 9.3000 & 78.9875 & 434 \\
\hline
\end{tabular}

${ }^{1}$ Combination of elevation recorded at study sites and WorldClim altitude data 

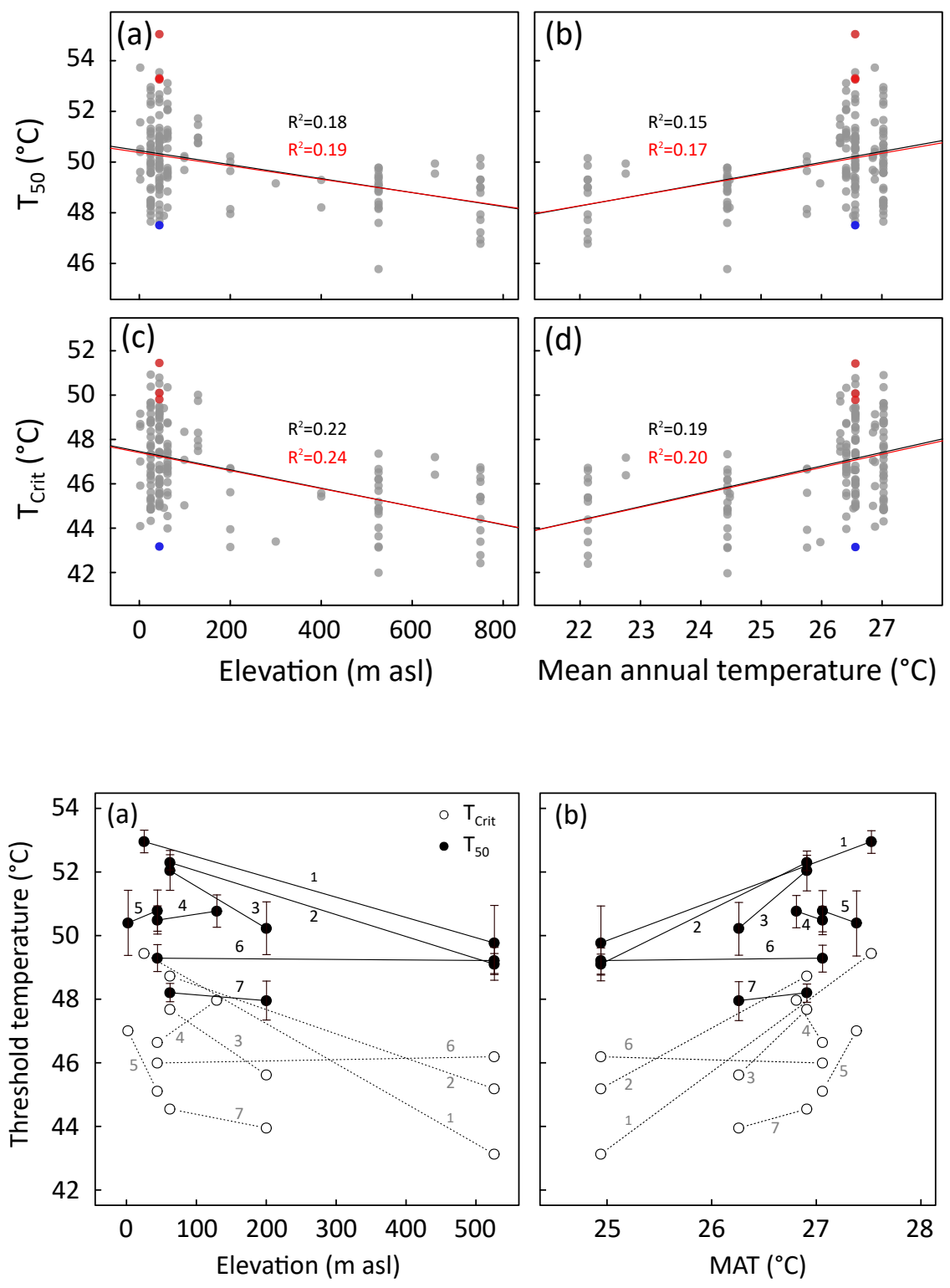


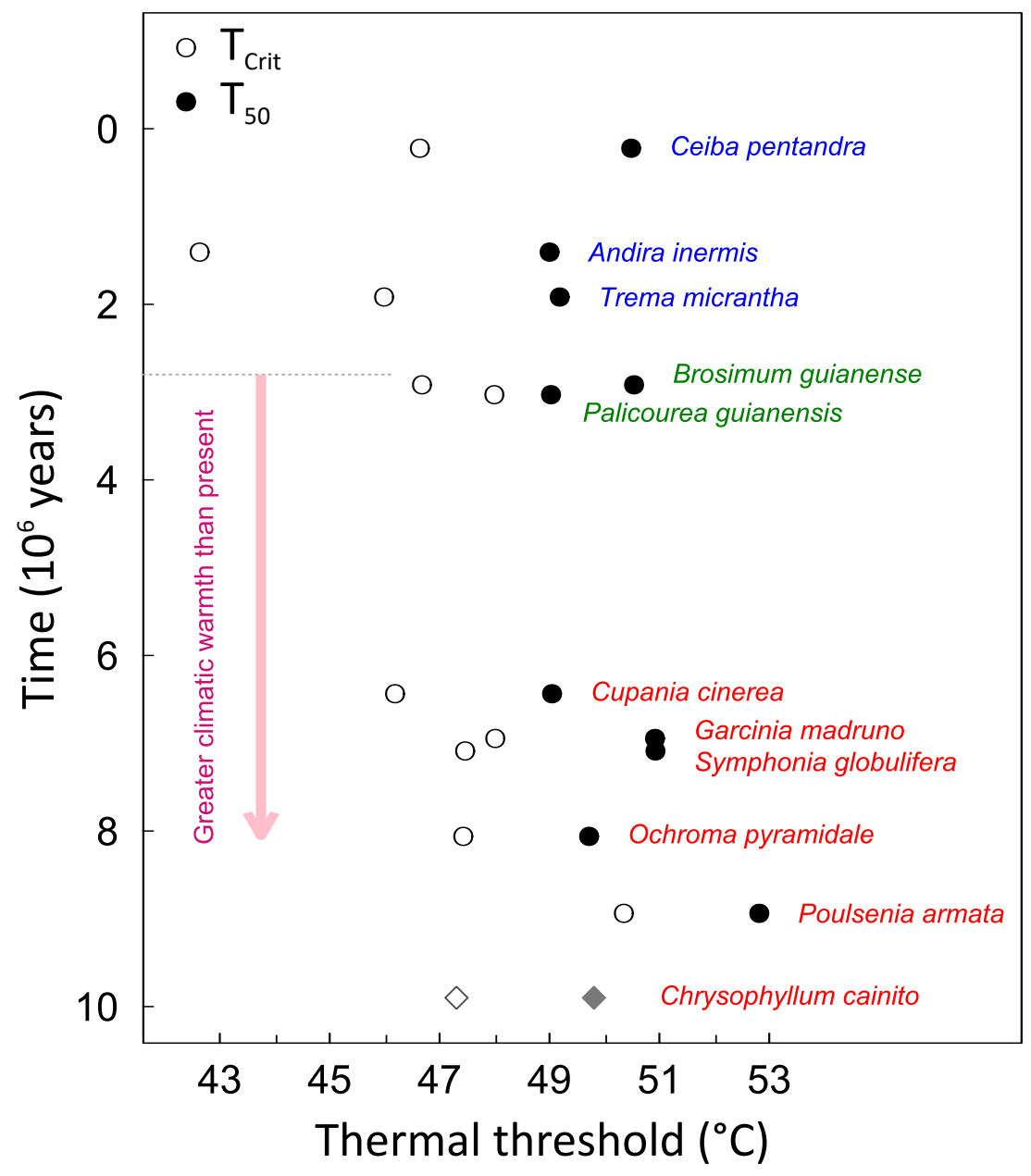



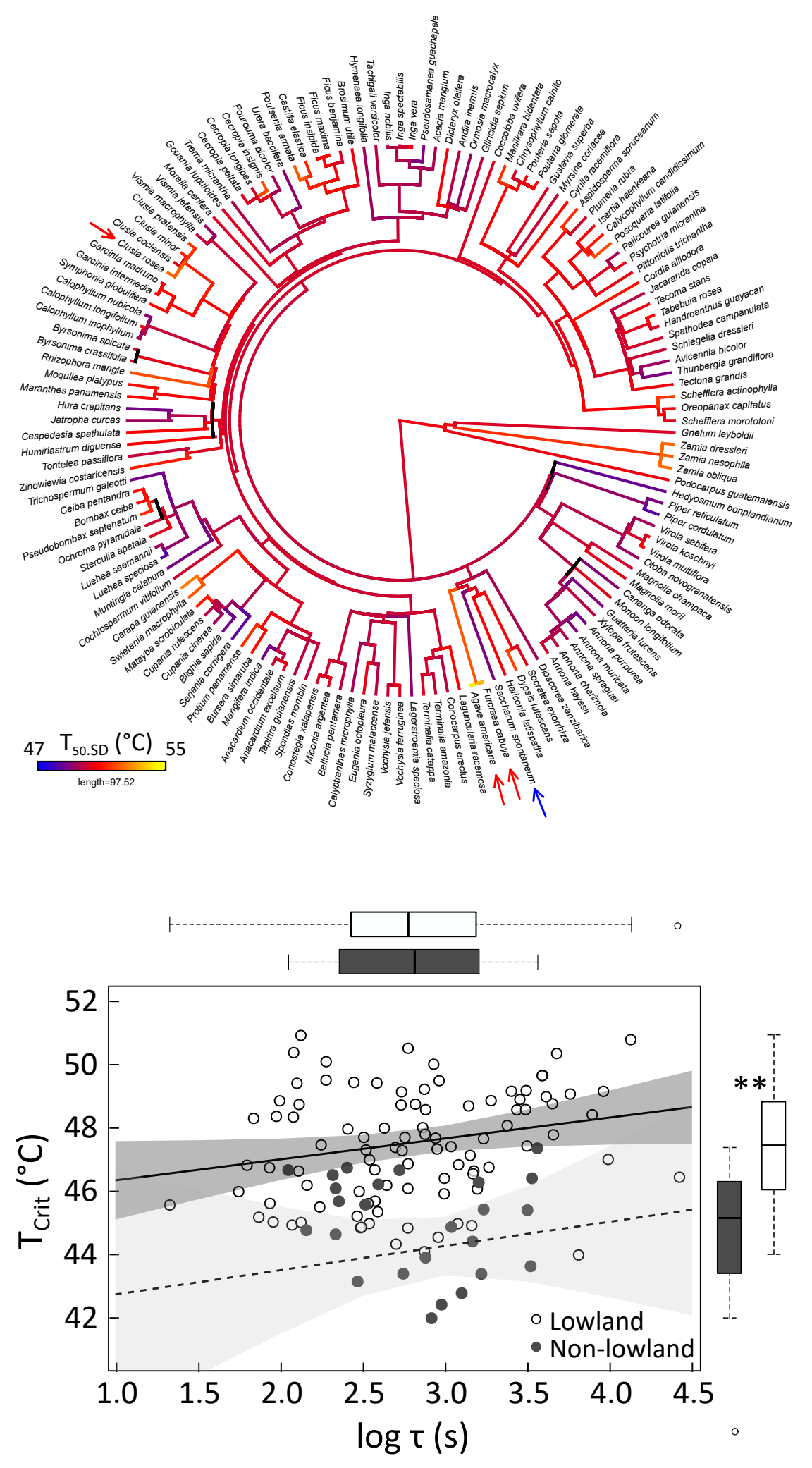


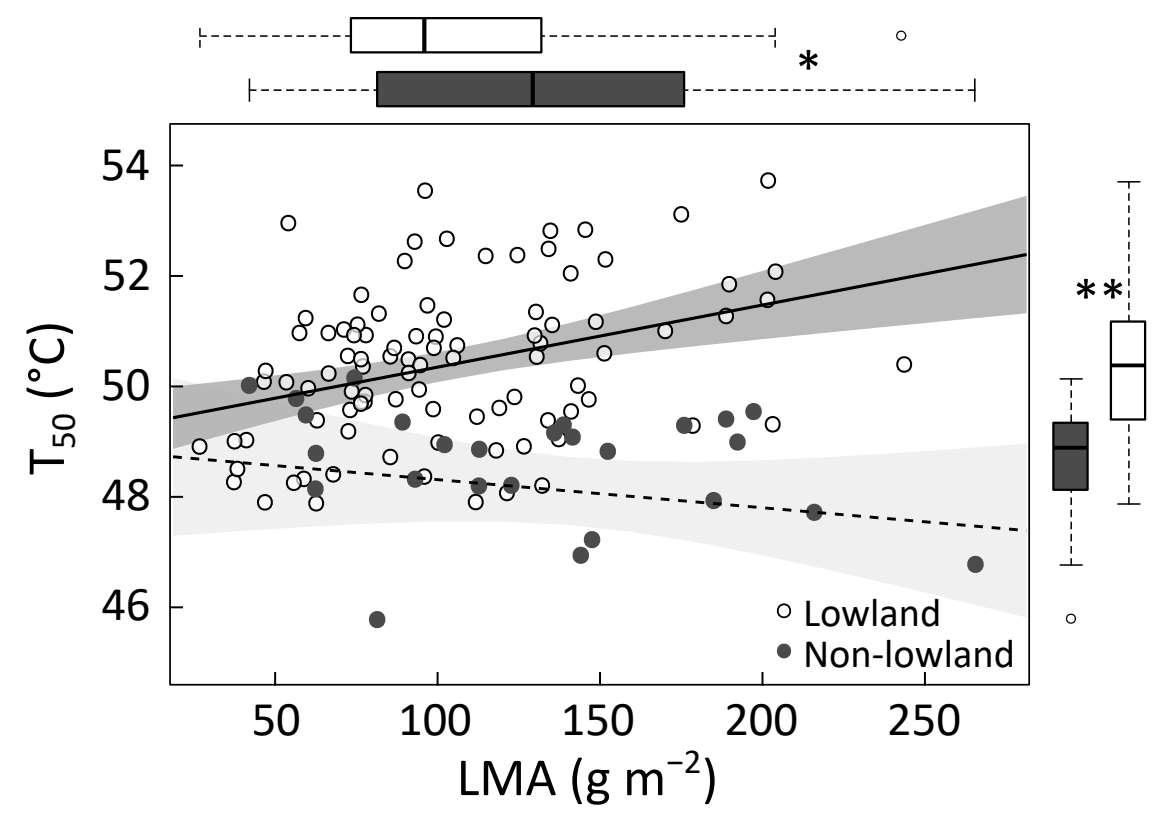

